УДК 351.86

КУШНІР В.О.

https://orcid.org/0000-0002-0805-4092

ІЖУТОВА I.В.

https://orcid.org/0000-0002-2614-7014

https://doi.org/10.33577/2313-5603.35.2021.3-17

\title{
ІСТОРИКО-РЕТРОСПЕКТИВНИЙ АНАЛІЗ ФОРМУВАННЯ ТА РОЗВИТКУ СИСТЕМИ СТРАТЕГІЧНИХ КОМУНІКАЦЙ У СЕКТОРІ БЕЗПЕКИ І ОБОРОНИ УКРАЇНИ
}

У статті зроблено історико-ретроспективний аналіз формування та розвитку системи стратегічних комунікацій у секторі безпеки і оборони України та запропоновано напрямки розвитку державного механізму стратегічних комунікацій (далі - СК) на основі унікального досвіду, отриманого під час роботи у районі бойових дій в ході Антитерористичної операції, операції Об'єднаних сил та досвіду держав - членів НАТО. Проаналізовано специфіку й ефективність найпоширеніших форм комунікацій у Міністерстві оборони та Збройних Силах України, обгрунтовано шляхи удосконалення державного механізму СК у секторі безпеки і оборони України. Особливістю війни гібридного типу є те, що вона добре замаскована і націлена не на фізичне захоплення усієї країни, а на отримання контролю над державою, який досягається через вплив на населення, політиків, бізнес, силові структури. Тому протидія гібридним загрозам вимагає уваги до підвищення стійкості всього суспільства. Базою джерел дослідження стали наукові праці щодо СК, нормативно-правова база та досвід роботи за напрямом СК.

Ключові слова: система стратегічних комунікацій, сектор безпеки і оборони України, історія розвитку стратегічних комунікацій в Україні.

Актуальність проблеми. Актуальність статті обумовлена пошуком ефективних способів діяльності органів державного управління в умовах стрімкого розвитку сучасного інформаційного світу, його динамічної зміни, підвищення рівня та кількості гібридних загроз, появи великої кількості дезінформації, неправдивої та маніпулятивної інформації, високого рівня пропаганди проти

Кушнір Вікторія Олександрівна, докторант навчально-наукового центру стратегічних комунікацій у сфері забезпечення національної безпеки та оборони Національного університету оборони України імені Івана Черняховського (м. Київ).

Іосутова Ірина Володимирівна, начальник кафедри стратегічних комунікачій навчально-наукового центру стратегічних комунікачій у сфері забезпечення нащіональної безпеки та оборони Начіонального університету оборони України імені Івана Черняховського (м. Киї).

(C) Кушнір В. О., Іжутова I.В., 2021 
України. Ефективною відповіддю боротьби 3 ними $є$ саме стратегічні комунікації (далі - СК), які $є$ скоординованим, комплексним і синхронізованим інструментом протидії викликам i загрозам сучасності, що успішно реалізується в державах членах НАТО, а в Україні був унормований з 2015 року.

Постановка проблеми. Пошук ефективних шляхів удосконалення роботи державних механізмів у сфері СК у секторі безпеки і оборони України залишається актуальним. На сьогодні питання функціонування системи СК у секторі безпеки i оборони, іiі нормативно-правове врегулювання розкриті доволі широко, але дослідженню становлення та розвитку системи в Україні не приділяється достатньої уваги.

Успішність реалізації процесу СК полягає у детальному аналізі набутого за останні роки вітчизняного досвіду та новітніх напрацювань країн-партнерів.

Виклад основного матеріалу. Побудова ефективної системи координації дій влади, синхронізація 3 основними каналами комунікації, функціонування єдиної системи взаємодії усіх органів влади в інформаційній сфері з метою узгодженого інформування різних аудиторій про ситуацію в Україні є актуальним завданням для нашої країни, зокрема в умовах інформаційної агресії. Головним комплексом заходів для реалізації зазначених завдань виступають СК. У вітчизняній науці СК стали об' єктом досліджень Г. Почепцова ще у 2008 році, який вказав на основні відмінності їх використання в державному управлінні, політиці та бізнесі як «м'яку силу» інформаційних операцій і їх вплив як інноваційний тип комунікаційного інструментарію. Автор також виділив компонент СК публічну дипломатію як метод просування своєї «картини світу» іноземним аудиторіям, а також обгрунтував сутність наративу та наративного контролю в контексті віртуального конструювання дійсності (Стратегические коммуникаџии: стратегические коммуникации в политике, бизнесе и государственном управлении, 2008: 23).

Пожвавлення СК в Україні зумовлюється необхідністю протистояння «гібридній агресії», що була розв'язана у 2014 році Російською Федерацією (далі - РФ) проти України.

Йдеться, зокрема, про нейтралізацію інформаційних впливів РФ, що дестабілізують міжнародні відносини та міжнародний інформаційний контент, уносять істотні збурення в міжнародну й внутрішню картину СК, світовий та регіональний «порядок денний». 
Питання розвитку системи СК в Україні на державному рівні було порушено у 2014 році за результатами ухвалених на Уельському саміті НАТО рішень щодо підтримки України в умовах агресії РФ. Альянс наголосив на тому, що володіє необхідними інструментами та процедурами для ефективної боротьби з гібридними загрозами, та підкреслив необхідність розвитку СК (Wales Summit Declaration, 2014).

Співпрацю Апарату Ради національної безпеки і оборони України (далі - РНБО) та НАТО у сфері СК розпочато у межах підготовки та проведення конференції «Стратегічні комунікаційні виклики: можливості реагування на дезінформацію у контексті гібридної війни» (У Києві відбувся семінар «Стратегічні комунікаційні виклики: можливості та реагування ..., 25 Nov. 2014).

Згодом у лютому 2015 року Місія України при НАТО висловила готовність розпочати переговори щодо започаткування програми Партнерства у сфері стратегічних комунікацій, а також запропонувала Апарату РНБО стати координаційним центром та головним партнером від української сторони у зазначеному проєкті.

Менш ніж за рік у Стратегії національної безпеки України було визначено нові загрози інформаційній безпеці держави, якто ведення інформаційної війни проти України та відсутність цілісної комунікативної політики держави, що може призвести до формування російськими засобами масової комунікації (далі 3МI) альтернативної до дійсності спотвореної інформаційної картини світу (Про Стратегію національної безпеки Украӥни, 2015).

У цей же час секретар РНБО України О. Турчинов та Генеральний секретар НАТО С. Столтенберг підписали Дорожню карту партнерства у сфері стратегічних комунікацій (далі Дорожня карта), де було визначені загальні цілі та завдання, формат співпраці, джерела фінансування та очікувані результати, а саме: розвиток здатності України здійснювати ефективні комунікації, що допоможуть забезпечити тіснішу взаємодію між усіма зацікавленими суб'єктами, як урядовими, так і неурядовими.

У Дорожній карті також визначено основні напрями роботи:

на стратегічному рівні - створення самодостатньої внутрішньовідомчої та урядової / міжвідомчої системи стратегічних комунікацій; розроблення і реалізація національної стратегії України у галузі стратегічних комунікацій; створення системи підготовки у галузі стратегічних комунікацій (підготовка інструкторів); 
на оперативному рівні - вдосконалення нормативних документів, що регламентують процес комунікації у структурах безпеки і оборони; підвищення ефективності державних 3MI;

на тактичному рівні - невідкладні заходи 3 підготовки наявного персоналу у галузі зв’язків з громадськістю/ публічної дипломатії в оборонних і безпекових структурах (Дорожня карта Партнерства у сфері стратегічних комунікачій..., 2015).

Імплементація Дорожньої карти започаткувала процес створення системи стратегічних комунікацій у державі та внесення змін до нормативно-правових документів загальнодержавного значення.

Термін «стратегічні комунікації», що включений до документів НАТО, сьогодні офіційно вживається в нормативноправових документах України. У Воєнній доктрині 2015 року «стратегічні комунікації» визначено як «скоординоване і належне використання комунікативних можливостей держави - публічної дипломатії, зв'язків із громадськістю, військових зв'язків, інформаційних і психологічних операцій, заходів, спрямованих на просування цілей держави» (Про нову редакцію Воєнної доктрини України, 2015).

Нормативним актом, в якому створення та впровадження системи СК у секторі безпеки і оборони окреслюється одним 3 основних напрямів ефективного розвитку сектору безпеки і оборони в сучасних умовах, став Указ Президента України від 14 березня 2016 року №92/2016 «Про рішення Ради національної безпеки i оборони України від 4 березня 2016 року «Про Концепцію розвитку сектору безпеки і оборони України». В цьому документі одним із принципів ефективного розвитку системи управління сектором безпеки і оборони вказані ефективні СК між суб'єктами сектору безпеки і оборони України (Про Концеепцію розвитку сектору безпеки і оборони України, 2016).

В оборонному відомстві одним із перших документів, що унормовував терміни та визначення СК, визначив суб' єктів СК та їх відповідальність, була Концепція стратегічних комунікацій Міністерства оборони України та Збройних Сил України, затверджена Наказом Міністерства оборони України від 22.11.2017 №612 (далі - Концепція). Відповідно до неї, «узгоджене та своєчасне застосування СК має вирішальне значення у протистоянні загрозам в інформаційному просторі, стає джерелом активного розповсюдження інформації у ЗМІ та реагування на поширення неправдивої інформації» (Наказ Міністерства оборони України № 612, 2017). 
Зазначимо, що у 2014 році підрозділи зі зв'язків 3 громадськістю, які частково виконували функції СК, міністерств і відомств, що входять до складу сектору безпеки і оборони України, не були готові до повноцінного протистояння гібридним атакам противника. Давалася взнаки недосконала технічна оснащеність, недостатній досвід роботи 3 іноземними ЗМІ в умовах кризи, відсутність досвіду роботи в умовах бойових дій; відсутність досконалої системи акредитації журналістів для їх роботи на сході України. На перших етапах існувала проблема розуміння вищим військовим керівництвом країни необхідності системної роботи 3 громадськістю. Системна робота була поетапно налагоджена лише через рік. Тож під час історикоретроспективного аналізу формування та розвитку системи СК у секторі безпеки і оборони України необхідно брати до уваги аналіз основних окремих системних елементів СК: зв'язків із громадськістю, публічної дипломатії, міжвідомчої координації, військових зв'язків $з$ громадськістю тощо.

3 початком інтенсивних бойових дій на сході України результатом скоординованої взаємодії представників структур сектору безпеки i оборони було прийняття рішення щодо формування першого об'єднаного пресцентру у районі ведення бойових дій 3 метою інформування населення України та міжнародної спільноти про події, що відбуваються в Україні. У роботі зазначеного пресцентру брали участь представники пресслужб Міністерства оборони України, Національної гвардії України, Міністерства внутрішніх справ України, Прикордонної служби України, Служби безпеки України та ін. Саме у цей час було сформовано медіапул українських журналістів, які висвітлювали події у районі проведення бойових дій та регулярно здійснювали виїзди на лінію зіткнення. У 2014 році кількість журналістів, які працювали щоденно у районі проведення Антитерористичної операції, сягала 50-70 чоловік, що ускладнювало роботу об'єднаного пресцентру. Спостерігалося значне навантаження на пресцентр через цілодобове інформування журналістів, щогодинні включення до прямих телевізійних ефірів, роботу зі спростування фейків, організацію та проведення брифінгів для представників українських та іноземних 3МI.

Вартим уваги залишається факт налагодження міжвідомчої координації комунікаційних підрозділів сектору безпеки і оборони. Завдяки зазначеній роботі з кінця 2015 року на базі інформагентства 
«Укрінформ» проводилися щотижневі спільні наради 3 метою обміну інформацією та координації планів щодо спільних заходів. До нарад запрошувалися представники Адміністрації Президента України, РНБО, Міністерства оборони України, Генерального штабу Збройних Сил України (далі - 3С України), Міністерства внутрішніх справ України, Національної гвардії України, Служби безпеки України, Міністерства закордонних справ України, Державної служби України із надзвичайних ситуацій та національні медіаексперти. Спільні рішення допомагали скоординовано та синхронізовано відповідати на гібридні виклики, робити це оперативно, якісно й переконливо. В ході таких дискусій формувалися й матеріали для щоденних брифінгів спікера Міністерства оборони, перевірялися втрати в ході бойових дій серед структур силового блоку.

Події, що розгорталися на сході України, згуртовували військових i цивільних громадян України. 3 початком другої хвилі мобілізації за ініціативи керівництва Міністерства оборони України проводився відбір серед мобілізованих із метою залучення до роботи у медіаструктурах оборонного відомства та 3С України. Перші 25 чоловік, серед яких були відомі українські журналісти, отримали відповідну фахову підготовку та посилили роботу підрозділів зв'язків з громадськістю ЗС України. У подальшому відбір таких кандидатів проводився на постійній основі.

Поступово налагоджувалися державні механізми у сфері зв'язків з громадськістю. У 2015 році завдяки скоординованим діям підрозділів зв'язків з громадськістю Міністерства оборони України та Служби безпеки України було удосконалено систему акредитації журналістів, розроблено дворівневу систему акредитації для їх роботи на сході України. Ця система передбачала видачу персоналізованих прескарт акредитованим представникам 3МI.

Починаючи з 2014 року, від початку російської агресії проти України, і до 2019 року, понад 6 тис. журналістів отримали акредитацію у районі бойових дій, серед них - приблизно 2 тис. представники іноземних 3МI.

У 2015 році за порадами американських експертів запроваджено проєкт «Embedded journalist», під час дії якого прикріплені до військової частини іноземні журналісти могли перебувати на лінії зіткнення тривалий час. Серед таких журналістів були представники найрейтинговіших світових 3МI. 
Налагоджувалися державні механізми у сфері публічної дипломатії: для інформування міжнародної спільноти у 2014 році започатковано проведення щотижневих зустрічей з військовими аташе 3 різних країн. Під час таких зустрічей представники іноземних держав були поінформовані про перебіг подій на лінії бойового зіткнення, отримували інформацію про сили і засоби агресора на території України та довкола іiї кордону, а також про роботу підрозділів ЗС України із цивільним населенням в районі ведення бойових дій.

У 2014 році одним із важливих об'єднуючих майданчиків для висвітлення подій в районі бойових дій та в Україні стала Громадська організація «Український кризовий медіа центр» (далі - УКМЦ). На базі УКМЦ на щоденній основі проводилися брифінги спікерів від Адміністрації Президента України, Міністерства оборони України, Міністерства внутрішніх справ України, Служби безпеки України, Державної служби України із надзвичайних ситуацій, які інформували про стан справ у районі бойових дій та надавали інформаційні докази російських військових злочинів в Україні представникам вітчизняних та іноземних 3МI.

У 2015 році було створено Міністерство інформаційної політики України (нині - Міністерство культури та інформаційної політики України) - колишній центральний орган виконавчої влади, який було визначено головним органом у системі центральних органів виконавчої влади, що забезпечує формування та реалізацію державної політики щодо інформаційного суверенітету України, державного іномовлення та інформаційної безпеки. Одним із основних завдань, покладених на Міністерство інформаційної політики, було забезпечення розбудови в Україні системи державних стратегічних комунікацій. Міністерством інформаційної політики було реалізовано серію важливих іміджевих та інформаційних проєктів (Про Доктрину інформаційної безпеки України, 2016).

Варто нагадати, що у 2014 - 2016 роках комунікаційні спроможності Міністерства оборони та 3С України реалізовувалися силами відомчого координуючого підрозділу із комунікації та залучених у сили і засоби Антитерористичної операції представників військових 3МI, таких як: Центральні друковані органи Міністерства оборони України газета «Народна армія», журнал «Військо України», газета «Крила України» та газета «Флот України», а також Центральна телерадіостудія та телерадіостудія «Бриз» Міністерства оборони України. 
У Доктрині інформаційної безпеки Міністерству оборони України були визначенні окремі завдання, у тому числі реалізація яких покладалася на військові ЗМІ Міністерства оборони України: організації зв'язків з українськими та іноземними ЗМІ щодо висвітлення ситуації в районі проведення Антитерористичної операції в Донецькій та Луганській областях; супроводження інформаційними засобами виконання завдань оборони України; донесення достовірної інформації до військовослужбовців ЗС України, інших військових формувань, зокрема через військові 3МI (Про Доктрину інформаційної безпеки України, 2017).

Для реалізації зазначених та інших завдань щодо роботи в умовах кризових ситуацій, а також удосконалення механізмів реалізації завдань 3 інформаційної безпеки Міністерством оборони України було реалізовано заходи 3 реформування підпорядкованих медійних структур.

Відповідно до Закону України «Про реформування державних і комунальних друкованих засобів масової інформації» та спільної директиви Міністерства оборони України та Генерального штабу 3С України, у 2018 році у Міністерстві оборони України проводились заходи реформування Центральних друкованих органів Міністерства оборони України - газети «Народна армія» та журналу «Військо України» (Про реформування державних $i$ комунальних друкованих засобів масової інформації, 2018).

Відповідно до Закону України «Про інформаційні агентства» (Закон Украӥни «Про інформачійні агентства», 2019) і Закону України «Про центральні органи виконавчої влади» (Закон України «Про центральні органи виконавчої влади», 2017) було прийнято рішення про створення Інформаційного агентства (далі - Інформаційне агентство) Міністерства оборони України, яке стало правонаступником Центральних друкованих органів Міністерства оборони України. Інформаційне агентство офіційно зареєстровано в Міністерстві юстиції України як повноправне державне інформаційне агентство.

Створення Інформаційного агентства дозволило інтегрувати в середовище забезпечення інформаційної безпеки України сучасну платформу, що здатна ефективно розвивати систему інформування суспільства про діяльність оборонного сектору 3 урахуванням сучасних інформаційних технологій та комунікаційних ресурсів. 
Суттєвим теоретико-методологічним підгрунтям розвитку цього напряму у вітчизняній науці став словник «Стратегічні комунікації» (2016), укладачами якого є В. Ліпкан і Т. Попова. Словник $є$ першим в Україні виданням, в якому з позицій системного підходу та сучасних інформаційних і комунікативних стратегій розглядається феномен СК та зібрані основні поняття й терміни. Автори на підставі вивчення досвіду держав - членів НАТО, де СК набули суттєвого наукового обгрунтування i практичного застосування, визначають, що вони охоплюють 17 складових компонентів та $є$ потужним інструментом у сфері безпеки та протидії гібридним загрозам (Попова Т.В., Ліпкан В.О. «Словник термінів стратегічних комунікацій», 2016).

У листопаді 2016 року у Національній академії Служби безпеки України відкрили перший курс зі стратегічних комунікацій для співробітників Служби безпеки України. Захід був ініційований співробітниками Академії та спрямований на реалізацію Дорожньої карти (В академії СБУ започатковано курси зі стратегічних комунікацій, 2016).

Партнери 3 держав - членів НАТО завжди підтримували Україну від початку російської агресії проти України. Об'єднана багатонаціональна комісія, започаткована влітку 2014 року, стала платформою для кращої реалізації допомоги, що надається для реформування 3С України та становлення системи СК у секторі безпеки і оборони України (Багатонаціональний об'єднаний координаиійний комітет: курс реформ ЗС Украӥни за стандартами HATO, 2019).

У березні 2016 року разом 3 неурядовою організацією «Spirit of America» започатковано новий проєкт задля налагодження зовнішньої та внутрішньої комунікації у секторі безпеки і оборони України - створення першого військового радіо «Армія $\mathrm{FM».} \mathrm{Сьогодні} \mathrm{це} \mathrm{радіо,} \mathrm{яке} \mathrm{систематично} \mathrm{інформує} \mathrm{ЗС} \mathrm{України} \mathrm{та}$ суспільство про ситуацію в районі бойових дій, життєдіяльність української армії та інші важливі події у секторі безпеки і оборони України. Протягом 2016 - 2021 років колективом військового радіо «Армія FM» підготовлено та випущено в ефір тисячі інформаційних, аналітичних, іміджевих, історичних, музичнорозважальних і культурно-просвітницьких проєктів, що інформували українське суспільство та міжнародну спільноту про події в Україні. 
Нова ефективна модель спілкування 3 громадськістю та забезпечення міжвідомчої координації, донесення наративів була запроваджена Департаментом інформації та комунікації 3 громадськістю Кабінету Міністрів України восени 2016 року. В рамках ініціативи «Сдиний голос» були об'єднані десятки комунікаційних підрозділів міністерств, органів центральної і місцевої влади, щоб спільно збирати, формувати та доносити до всіх зміст урядових реформ. Щотижня Департамент інформації та комунікацій з громадськістю Кабінету Міністрів України збирав представників комунікаційних підрозділів міністерств та відомств на зустріч, під час якої вони обмінювалися інформацією, узгоджували дії в рамках кампаній, аналізували результати попередніх заходів та обговорювали проблемні питання. На підставі інформації від урядових пресслужб Департамент інформації та комунікацій з громадськістю Кабінету Міністрів України готував тижневий комунікаційний план Уряду i контролював його виконання. Під час реалізації планів проєкту «Сдиний голос» було проведено близько тисячі заходів за участі перших осіб Уряду, міністрів та глав відомств - брифінгів, пресконференцій, інтерв'ю, теле і радіоефірів, десятки круглих столів. (Ми активно розвиваємо урядову комунікаційну стратегію «Єдиний голос», Роксолана Стадник, 2018).

У 2016 році на рівні керівництва Міністерства оборони України було прийнято рішення щодо необхідності координації діяльності всіх органів і підрозділів відомства, задіяних в інформаційній діяльності. 3 цією метою було створено новий підрозділ - Відділ координації стратегічних комунікацій та моніторингу Міністерства оборони України. Його задачею була координація та контроль реалізації СК у Міністерстві оборони України та ЗС України, міжвідомчої комунікації у сфері СК та моніторингу (Наказ Міністра оборони Украӥни №390, 2019).

Міністерство закордонних справ України традиційно приділяло увагу проведенню тренінгів для дипломатів із питань комунікацій та публічної дипломатії. Зокрема, лише у 2016 році було проведено тренінги 3 комунікацій для групи керівників закордонних дипломатичних установ України (у взаємодії з Посольством США в Україні) щодо публічних інструментів протидії гібридним загрозам та щодо нових викликів і можливостей для дипломатії у сфері лобіювання інтересів України на міжнародній арені. 
Міністерство закордонних справ продовжує активно взаємодіяти 3 міжнародними партнерами 3 метою обміну досвідом у сфері стратегічних комунікацій. Зокрема, налагоджена співпраця 3 НАТО, СС, США, Великою Британією. Представники міністерства беруть участь у роботі групи «Друзі України 3 питань стратегічних комунікацій», що об'єднує представників держав - членів ЄС, США та Канади (МЗС України вперше сформує стратегію публічної дипломатї̈, 2020).

Інші міністерства теж розвивали систему СК, так, у 2018 році у Міністерстві внутрішніх справ України був створений відділ стратегічних комунікацій та координації сектору безпеки з питань євроатлантичної інтеграції, який став самостійним структурним підрозділом Апарату Міністерства внутрішніх справ України, підпорядкованим секретареві Міністерства внутрішніх справ.

У 2019 році розпочато діяльність Навчально-наукового центру стратегічних комунікацій у сфері забезпечення національної безпеки та оборони Національного університету оборони України імені Івана Черняховського, основними завданнями якого є підготовка та підвищення кваліфікації військовослужбовців і працівників структур сектору безпеки і оборони з питань стратегічних комунікацій, науково-методичне забезпечення процесу підготовки, проведення наукових досліджень 3 проблематики стратегічних комунікацій та здійснення міжнародної співпраці зі схожими за специфікою науково-дослідними установами.

У 2020 році в Апараті командувача Національної гвардії України була створена служба стратегічних комунікацій Головного управління Національної гвардії України.

Також у 2020 році керівництво Міністерства оборони України прийняло рішення щодо створення Директорату інформаційної політики у сфері оборони та стратегічних комунікацій Міністерства оборони України, основною задачею якого є участь у формуванні, координації та моніторингу реалізації державної інформаційної політики 3 питань національної безпеки у воєнній сфері, забезпечення формування системи стратегічних комунікацій та визначення шляхів іiі становлення та розвитку в Міністерстві оборони України, ЗС України та Державній спеціальній транспортній службі як складової загальнодержавної системи стратегічних комунікацій та координації діяльності суб'єктів стратегічних комунікацій Міністерства оборони України, Збройних Силах 
України та Державної спеціальної транспортної служби (Про затвердження Положення про Директорат інформаційної політики y сфері оборони та стратегічних комунікачій Міністерства оборони Украӥни, 2020).

Крім того, у 2020 році у Генеральному штабі 3С України було створено Управління стратегічних комунікацій Апарату Головнокомандувача ЗС України. Цього ж року розроблено та прийнято Доктрину зі стратегічних комунікацій. Документ призначено для використання посадовими особами в органах військового управління, які виступають суб'єктом стратегічних комунікацій або реалізовують завдання інформаційної політики у ЗС України, та може бути використана на будь-якому рівні в межах процесів реформування або в ході підготовки та проведення операцій Об'єднаних сил. Розробка Доктрини базувалася на передовому досвіді та актуальних директивах НАТО щодо стратегічних комунікацій, а також наукових доповідях, статтях та інших публікаціях 3 цієї тематики (Доктрина зі стратегічних комунікащій, 2020, с. 2).

Висновки. Отже, виходячи $з$ проведеного аналізу ми прийшли до висновку, що на початковому етапі ведення Російською Федерацією інформаційної агресії проти України вітчизняні державні органи продемонстрували певну недостатню спроможність протидіяти агресору в інформаційній сфері. Згодом, розвиваючи співпрацю з НАТО з питань СК, Україна започаткувала процес розбудови СК, що триває й сьогодні. Найактивніше розбудовує систему СК у секторі безпеки і оборони Міністерство оборони України. Результати роботи у 2014-2019 роках свідчать про ефективність проведених заходів, зокрема в умовах жорсткого протистояння гібридній війні.

Вивчення досвіду, набутого під час забезпечення заходів із захисту країни від збройної агресії у згаданий період, дозволить усунути недоліки в роботі СК, вдосконалити систему кризових комунікацій та розвинути ефективну систему СК, зокрема враховуючи передовий досвід держав - членів НАТО та СС.

Невирішені питання залишаться предметом подальшого дослідження з метою вдосконалення системи СК в Україні.

\section{Використані посилання}

Багатонаціональний об’ єднаний координаційний комітет: курс реформ ЗС України за стандартами НАТО (03 червня 2019 року). Доступно: https://www.mil.gov.ua/ news/2019/06/03/bagatonaczionalnij-obednanij-koordinaczijnij-komitet-kurs-reform-zsukraini-za-standartami-nato/. [Дата звернення: 01.04.2021]. 
В академії СБУ започатковано курси зі стратегічних комунікацій (03 листопада 2016 року). Доступно: http://academy.ssu.gov.ua/ua/news/V-Akadem-SBU-zapochatkovanokursi-z-strategchnih-komunkacy.htm. [Дата звернення: 01.04.2021].

Доктрина зі стратегічних комунікацій ВКП 10-00(49).01, 2020, С. 2

Дорожня карта Партнерства у сфері стратегічних комунікацій між Радою національної безпеки і оборони України та Міжнародним секретаріатом НАТО, 2015. Доступно: http://surl.li/bwzv. [Дата звернення: 01.04.2021].

МЗС України вперше сформує стратегію публічної дипломатії, 10 вересня 2020 року). Доступно: https://mfa.gov.ua/news/mzs-ukrayini-vpershe-sformuye-strategiyupublichnoyi-diplomatiyi [Дата звернення: 01.04.2021].

Ми активно розвиваємо урядову комунікаційну стратегію «Сдиний голос», Роксолана Стадник (11 травня 2018 року). Доступно: https:/www.kmu.gov.ua/news/ miaktivno-rozvivayemo-uryadovu-komunikacijnu-strategiyu-yedinij-golos-roksolana-stadnik. [Дата звернення: 01.04.2021].

Про затвердження Положення про Директорат інформаційної політики у сфері оборони та стратегічних комунікачій Міністерства оборони Украӥни: Наказ Міністерства оборони України № 309 від 31.08.2020. Доступно: https://www.mil.gov.ua/ content/mou_orders/mou_2020/nm309.PDF. [Дата звернення: 01.04.2021].

Про затвердження Положення про Відділ координації стратегічних комунікаџій та моніторингу: Наказ Міністерства оборони Украйни № 390 від 18.07.2019. Доступно: https://www.mil.gov.ua/content/mou_orders/mou_390.pdf. [Дата звернення: 01.04.2021].

Попова Т.В., Ліпкан В.А. (2016). Стратегічні комунікації: [словник] К .: ФОП О. С. Ліпкан, - 416 с.

Про нову редакиію Воєнної доктрини України: Указ Президента Украӥни № 555/2015 від 24.09.2015. Доступно: https://zakon.rada.gov.ua/laws/ show/555/ 2015\#Text. [Дата звернення: 01.04.2021].

Почепцов Г.Г. (2008). Стратегические коммуникации: стратегические коммуникации в политике, бизнесе и государственном управлении. Киев: Альтпресс. С. 23.

У Києві відбувся семінар "Стратегічні комунікачійні виклики: можливості та реагування на дезінформацію у контексті гібридної війни», 25 Nov. 2014 Доступно: https://www.nato.int/cps/en/natohq/news_116755.htm. [Дата звернення: 01.04.2021].

Wales Summit Declaration, 05 Sep. 2014. Доступно: https://www.nato.int/cps/en/ natohq/official_texts_112964.htm. [Дата звернення: 01.04.2021].

Про Концепцію розвитку сектору безпеки і оборони Украӥни: Указ Президента України №92/2016 від 14.03.2016. Доступно: https://www.president.gov.ua/documents/ 922016-19832. [Дата звернення: 01.04.2021].

Концепція стратегічних комунікацій Міністерства оборони Украӥни та Збройних Сил України, Наказ Міністерства оборони Украӥни № 612 від 22.11.2017. Доступно: https://zakon.rada.gov.ua/rada/show/v0612322-17\#Text. [Дата звернення: 01.04.2021].

Про иентральні органи виконавчої влади: Закон Украӥни, 2017.

Про інформаційні агентства: Закон Украӥни, 2019.

Про реформування державних $і$ комунальних друкованих засобів масової інформації: Закон України, 2018.

Про Доктрину інформаційної безпеки України: Указ Президента України від 25.02.2017 № 47/2017. Доступно: https://www.president.gov.ua /documents/ 472017-21374. [Дата звернення: 01.04.2021]. 


\section{References}

Multinational Joint Coordination Committee: UAF reforms under NATO standards (June 03 ${ }^{\text {rd }}$, 2019). URL: https://www.mil.gov.ua/news/2019/06/03/bagatonaczionalnijobednanij- koordinaczijnij-komitet-kurs-reform-zs-ukraini-za-standartami-nato/. [ukr].

Strategic communications course launched in SSU Academy (November 03, 2016). URL: http://academy.ssu.gov.ua/ua/news/V-Akadem-SBU-zapochatkovanokursi-z-strategchnih-komunkacy.htm. [ukr].

Strategic Communications Doctrine, 2020, p. 2. [ukr].

Strategic Partnership Roadmap signed by National Security and Defence Council of Ukraine and NATO International Secretariat, 2015. URL: http://surl.li/bwzv. [ukr].

For the first time the Ministry of Foreign Affairs of Ukraine to develop public diplomacy strategy, September 10, 2020). URL: https://mfa.gov.ua/news/mzsukrayini-vpershe-sformuye-strategiyu-publichnoyi-diplomatiyi [ukr].

We develop actively the govt communication strategy One Voice, Roksolana Stadnyk (May 11, 2018). URL: https://www.kmu.gov.ua/news/mi-aktivno-rozvivayemo-uryadovukomunikacijnu-strategiyu-yedinij-golos-roksolana-stadnik. [ukr].

On approval of Regulations on Directorate of defence information policy an strategic communications of the Ministry of Defence of Ukraine No.309 dd 31.08.2020. URL: https://www.mil.gov.ua/content/mou_orders/mou_2020/nm309. PDF. [ukr].

On approval of Regulations on Strategic Communications Coordination and Monitoring Section: Ministry of Defence of Ukraine Order No.390 dd 18.07.2019. URL: https://www.mil.gov.ua/content/mou_orders/mou_390.pdf. [ukr].

Popova T.V., Lipkan V.A. (2016). Strategic communications: [vocabulary] K .: PEE O.S. Lipkan. -416 c.

On new version of Military Doctrine of Ukraine: Presidential Decree of Ukraine No.555/2015 dd 24.09.2015. URL: https://zakon.rada.gov.ua/laws/show/555/2015\#Text. [ukr].

Pocheptsov G.G. (2008). Strategic communications: strategic communications in policy, business and public administration. Kiev: Altpress. p. 23. [ukr].

Kyiv hosts seminar 'Strategic Communication challenges: capabilities and disinformation response within hybrid warfare, 25 Nov. 2014 URL: https://www.nato.int/cps/en/ natohq/news_116755.htm. [ukr].

Wales Summit Declaration, 05 Sep. 2014. URL: https://www.nato.int/cps/en/ natohq/official_texts_112964.htm. [ukr].

On Concept of development of security and defence sector of Ukraine: Presidential Decree of Ukraine No.92/2016 dd 14.03.2016. URL: https://www.president.gov.ua/documents/922016-19832. [ukr].

Concept of Strategic Communications of the Ministry of Defence of Ukraine and Armed Forces of Ukraine, Order of the Ministry of Defence of Ukraine No. 612 dd 22.11.2017. URL: https://zakon.rada.gov.ua/rada/show/v0612322-17\#Text. [ukr].

On central executive authorities: Law of Ukraine, 2017.

On information agencies: Law of Ukraine, 2019.

On reforms of state and municipal publishing houses: Law of Ukraine, 2018.

On information security doctrine of Ukraine: Presidential Decree of Ukraine Bid No.47/2017 dd 25.02.2017. URL: https://www.president.gov.ua/ documents/47201721374. [ukr]. 


\section{Kushnir V., Izhutova I. \\ HISTORICAL RETROSPECTIVE ANALYSIS OF FORMATION AND DEVELOPMENT OF STRATEGIC COMMUNICATIONS SYSTEM IN SECURITY AND DEFENCE OF UKRAINE}

The article is dedicated to the historical retrospective analysis of formation and development of strategic communications system in security and defence of Ukraine. The authors have proposed the prospective development of state mechanism of strategic communications based on the unique experience gained during work within combat operations region of the anti-terror operation, Joint Forces Operation, as well as NATO nations' experience. The authors have analysed the specifics and effectiveness of widely used communications forms in the Ministry of Defence and Armed Forces of Ukraine, justified the prospects of improvement of the state strategic communications mechanism in security and defence of Ukraine.

The research is based on scientific works on strategic communications, normative and legal documents and personal experience in strategic communications during work within the Ministry of Defence of Ukraine. The actuality of the article is seen in the search of effective methods of state authorities work within evolving information world, its dynamic change, raised level and number of hybrid threats, great number of disinformation, false and manipulative information, and high level of anti-Ukrainian propaganda. The strategic communications as coordinated, comprehensive, and synchronized tool are effective in fighting against the above-mentioned. This tool is successfully implemented within the NATO nations, while Ukraine implemented it in the legislative documents in 2015.

Today the issue of strategic communications system within security and defence sector, its legislative regulation is widely covered but the process of its formation and development in Ukraine was not researched thoroughly.

The strategic communications could be successfully implemented based on the analysis of the latest national experience and researches of the partner nations.

Keywords: state mechanisms of strategic communications, sector of safety and defence of Ukraine, history of development strategic communication in Ukraine. 